\title{
HIPNOBREASFEEDING DAN PIJAT OKSITOSIN BERPENGARUH TERHADAP PENGELUARAN KOLOSTRUM PADA IBU POST PARTUM
}

\author{
Hamidah, Shentya Fitriana \\ Poltekkes Kemenkes Jakarta III \\ Email:hamidah.hk59@yahoo.com
}

\begin{abstract}
Woman are blessed by The Almight God to conceive, give birth, and breastfeed. The nature given to the woman is characterized by the existence of its reproductive organs, such as uterus where the fetus grows and develops in the womb, breasts which breastfeed milk is produced so that the mother can breastfeed her baby at the beginning of childbirth. It means that all women have the potential to breastfeed their babies, just as their potential to conceive and deliver (Perinesia, 2010). At the early labor many post-partum mothers complain that their breastfeed milk cannot or not yet to be released that they cannot give colostrums to their baby at the beginning of their birth. One effort that can be done to help release the colostrum is by doing hypnobreasfeeding, oxytocin massage to the post-partum mothers 2-6 hours.This study discusses the effect of hypnobreastfeeding, the oxytocin massage on the releasing time of colostrum to the post-partum mothers 2-6 hours. This research used quantitative method. Respondents are post-partum mothers who performed hypnobreasfeeding, massage of oxytocin. The research design was Quasi Experiment. Sampling was done by purposive sampling of 70 respondents. The research results showed that parity was related to colostrum release at 4 hours post partum ( $p$ value $=0.020)$. Multivariate analysis proved that the most dominant factor that influenced colostrum release was multi-gravid parity by hypnobreastfeeding and oxytocin massage at 4 hours of post partum.
\end{abstract}

Keywords: hypnobreastfeeding, oxytocin massage, colostrum.

\section{ABSTRAK}

Perempuan mendapat anugrah dari Tuhan Yang Maha Esa untuk dapat mengandung, melahirkan dan menyusui. Kodrat yang diberikan kepada perempuan tersebut ditandai dengan adanya komponen alat reproduksi yang dimilikinya, yaitu rahim tempat tumbuh dan berkembangnya janin selama didalam kandungan, dan payudara untuk tempat diproduksinya ASI sehingga ibu dapat menyusui bayinya pada awal kelahiran. Itu artinya semua perempuan mempunyai potensi untuk menyusui bayinya, sama seperti potensinya untuk dapat mengandung dan melahirkan (Perinasia, 2010). Pada awal persalinan banyak ibu post partum mengeluh ASInya tidak atau belum keluar sehingga tidak bisa memberikan kolostrum kepada bayinya diawal kelahirannya. Salah satu upaya yang bisa dilakukan untuk membantu mengeluarkan kolostrum yaitu dengan melakukan hypnobreasfeeding, pijat oksitosin pada ibu post partum 2-6 jam. Penelitian ini membahas pengaruh hypnobreasfeeding, pijat oksitosin terhadap waktu pengeluaran kolostrum pada ibu post partum $2-6$ jam. Penelitian ini menggunakan metode kuantitatif. Subjek penelitian adalah ibu post partum yang dilakukan hypnobreasfeeding, pijat oksitosin. Desain penelitian adalah Quasi Eksperiment.Pengambilan sampel dilakukan secara purposive samplingsebanyak 70 responden. Hasil penelitian menunjukkan bahwa paritas berhubungan terhadap pengeluaran kolostrum pada 4 jam post partum ( $p$ value=0,020), Analisis multivariat membuktikan bahwa faktor dominan yang paling berpengaruh terhadap pengeluaran kolostrum adalah paritas multi gravida yang dilakukan hypnobreasfeeding dan pijat oksitosin pada 4 jam masa nifas.

Kata kunci : hipnobreasfeeding, pijat oksitosin, kolostrum. 


\section{PENDAHULUAN}

Undang-UndangDasar 1945 Pasal 28 Ayat 2 menyebutkan bahwa setiap anak berhak atas kelangsungan hidupnya, tumbuh dan berkembang serta berhak atas perlindungan dari kekerasan dan diskriminasi. Selain itu Undang-Undang No. 36 Tahun 2009 tentang kesehatan, pada pasal 128 ayat 1 menyebutkan bahwa setiap bayi berhak mendapatkan Air Susu Ibu secara Eksklusif sejak dilahirkan sampai usia bayi 6 bulan. Dalam Pasal ini juga yaitu pada ayat 2 disebutkan: bahwa selama pemberian Air Susu Ibu, pihak keluarga, pemerintah, pemerintah daerah dan masyarakat harus mendukung ibu secara penuh dalam pemberian ASI dengan menyediakan waktu dan fasilitas khusus (Permeneg Pemberdayaan Perempuan dan Perlindungan Anak Republik Indonesia No. 03 Tahun 2010).

Dukungan pemerintah Republik Indonesia terhadap pemberian ASI Eklusif telah dilakukan dengan berbagai upaya melalui Gerakan Nasional Peningkatan Penggunaan Air Susu Ibu (GNPP- ASI ), Gerakan Masyarakat Peduli ASI dan Kebijakan Peningkatan Penggunaan Air Susu Ibu ( PP- ASI ). Tetapi dalam kenyataan hanya $4 \%$ bayi yang mendapatkan Air Susu Ibu pada 1 jam pertama kelahirannya dan $8 \%$ bayi yang mendapatkan ASI Eklusif. Padahal sejak tahu 2000 pemerintah telah menargetkan pencapaian pemberian ASI Ekslusif sebanyak $80 \%$ ( Roesli, 2008.)

Air Susu Ibu adalah makanan terbaik untuk bayi sampai berusia 2 tahun. Karena ASI atau menyusui akan memberikan awal terbaik bagi kehidupan anak. Diperkirakan hampir kurang lebih satu juta anak meninggal setiap tahunnya, hal ini disebabkan karena anak menderita diare, penyakit saluran napas bagian atas dan infeksi lainnya. Hal ini terjadi bayi atau anak tidak mendapatkan ASI secara memadai. Menyusui juga dapat membantu melindungi kesehatan ibu (Perinasia, 2010 ).

Air Susu Ibu dapat mencerdaskan dan meningkatkan kualitas generasi penerus bangsa, karena setiap bayi yang mendapatkan ASI secara memadai dan berkualitas akan mendapatkan kekebalan secara alami, karena ASI banyak mengandung zat antibodi, zat kekebalan aktif yang akan menghalangi masuknya infeksi kedalam tubuh bayi. Saat ini sekitar $40 \%$ kematian balita terjadi pada satu bulan pertama kehidupannya, diharapkan dengan pemberian ASI akan berkurang menjadi 22\% kematian bayi dibawah usia 28 hari, dengan demikian melalui pemberian ASI secara Eklusif secara dini 
maka kematian bayi dan balita dapat dicegah ( Roesli, 2008 ).

Semua perempuan mempunyai potensi untuk memberikan ASI kepada anaknya, namun tidak semua ibu post partum dapat langsung mengeluarkan ASI. Pengeluaran ASI merupakan interaksi yang sangat komplek antara rangsangan mekanik, syaraf dan bermacam-macam hormon yang mempengaruhi keluarnya oksitosin. Pengeluaran hormon oksitosin dapat dipengaruhi oleh isapan pada puting susu ibu, dipengaruhi oleh sistem duktus, bila duktus melebar atau menjadi lunak maka secara reflektoris oksitosin akan keluar oleh kelenjar hipofiseyang berperan untuk memeras ASI dari alveoli.

Produksi ASI dipengaruhi oleh hormon prolaktin, sedangkan pengeluarannya dipengaruhi oleh hormon oksitosin. Upayaupaya yang dilakukan yang dilakukan untuk mengeluarkan ASI pada beberapa ibu post partum yang bermasalah terhadap pengeluaran ASInya salah satunya adalah dengan melakukan hypnobreasfeeding, pijat oksitosin secara dini. Hormon oksitosin akan keluar melalui rangsangan pada puting susu ibu melalui isapan mulut bayi atau dapat juga dilakukan melalui hypnobreasfeeding, pijatan pada tulang belakang ibu, efek pijatan pada tulang belakang dan tindakan hypnobreasfeeding ibu akan merasa tenang, rileks, ikatan psikologis antara ibu dan bayi, ibu lebih mencintai bayinya, ambang rasa nyeri berkurang sehingga ASI cepat keluar.

Pijatan pada tulang belakang akan menyebabkan neurotransmiter merangsang medulla oblongata langsung mengirim pesan ke hypotalamus pada hipopyse posterior untuk mengeluarkan oksitosin sehingga menyebabkan buah dada terisi dan terasa mengencang untuk mengeluarkan air susu. Pijatan pada daerah tulang belakang ini juga akan merileksasi ketegangan dan menghilangkan stress sehingga akan membantu pada saat segera setelah bayi lahir dengan keadaan bayi yang lahir normal ( Guyton, 2009 ).

Metode hypnobreasfeeding sangat tepat digunakan pada ibu post partum yang bermasalah dengan pengeluaran kolostrum atau ASI, karena pada situasi ini ibu akan merasa rileks, tenang, percaya diri, lebih siap untuk menyusui bayinya, sehingga akan berpengaruh terhadap produksi ASInya. Hypnobreasfeeding adalah salah satu upaya alami dengan menggunakan energi bawah sadar agar proses menyusui berjalan aman dan lancar, serta ibu dapat menghasilkan ASI yang mencukupi untuk kebutuhan tumbuh kembang bayi.

Sebagian ibu post partum dan keluarga menganggap bahwa untuk memberikan ASI kepada bayi keadaan payudara ibu harus penuh dan terasa keras, keluar 
ASInya kental dan banyak, sehingga banyak ibu post partum mengalami pembengkakan pada payudaranya atau terjadi mastitis (peradangan pada payudara), hal ini terjadi akibat ibu terlambat memberikan asi pada bayinya karena ketidak tahuan ibu post partum atau keluarga tentang bagaimana usaha-usaha untuk mengeluarkan ASI. ( Varney, 2009 ) Berdasarkan uraian diatas, maka peneliti merasa tertarik untuk melakukan penelitian dengan judul Pengaruh Hypnobreasfeeding, Pijat Oksitosin, dan kombinasi perlakuan hypnobreasfeeding pijat oksitosin, pada ibu post partum $2-6$ jam di wilayah kerja, Rumah Bersalin di wilayah kerja Puskesmas Kecamatan Cimanggis.

Penelitian ini dilakukan untuk mengetahui pengaruh Hypnobreasfeeding, Pijat Oksitosin terhadap pengeluaran kolostrum

\section{METODE}

Merupakan penelitian kuantitatif dengan desain Quasi Eksperiment. Penelitian dilakukan diwilayah kerja Puskesmas Kecamatan Cimanggis dilaksanakan dari HASIL DAN PEMBAHASAN bulan April sampai September 2016. Sampel penelitian adalah ibu post partum yang berkunjung ke Puskesmas dari bulan April sampai September 2016. Jumlah sampel sebanyak 70 responden, dengan teknik purposive sampling.

Pengumpulan data dilakukan menggunakan data primer dengan menggunakan lembar observasi, lembar ceklist, panduan dan observasi langsung pada saat ibu post partum dilakukan intervensi Hypnobreasfeeding dan pijat oksitosin.

Analisa data menggunakan 3 tahapan yaitu mulai dari analisis univariat, bivariat dan multivariat. Analisis multivariat menggunakan ancova dengan tujuan untuk melihat variabel mana yang paling dominan berpengaruh terhadap pengeluaran kolostrum.

Penelitian ini menerapkan lima prinsip etik penelitian, yaitu Respect for person (menghormati harkat dan martabat manusia), Beneficence (bermanfaat), Justice (keadilan), Risk and benefit (tidak merugikan), Informed consent (persetujuan) 
Tabel 1.

Distribusi Frekuensi Karakteristik Responden terhadap waktu Pengeluaran Kolostrum postpartum di Puskesmas Kecamatan Cimanggis Tahun 2017

\begin{tabular}{lcc}
\hline \multicolumn{1}{c}{ Variabel } & Frekuensi & Persentase ( \% ) \\
\hline Usia Reproduksi : & & \\
Reproduksi Sehat & 59 & 79,7 \\
Resiko & 15 & 20,3 \\
Paritas : & 48 & 64,9 \\
Multi Gravida & 26 & 35,1 \\
Primi Gravida & & \\
Waktu PengeluaranKolostrum 2 jam : & 19 & 25,7 \\
Ya & 55 & 74,3 \\
Tidak & & 60,8 \\
Waktu Pengeluaran Kolostrum 4 jam : & 45 & 39,2 \\
Ya & 29 & 100 \\
Tidak & & - \\
Waktu Pengeluaran Kolostrum 6 jam : & 74 & 48,6 \\
Ya & - & 51,4 \\
Tidak & & \\
Metode Pengeluaran & 36 & \\
Hypnobreasfeding & 38 & \\
Pijat Oksitosin & & \\
\hline
\end{tabular}

Berdasarkan tabel 1. Mengambarkan bahwa darri 74 responden, $79,7 \%$ berusia reproduksi sehat, $64,9 \%$ paritas multigravida. Waktu pengeluaran kolostrum $25,7 \%$ pada 2 jam pertama, $60,8 \%$ pada 4 jam pertama dan $100 \%$ pada 6 jam pasca salin. Metode pengeluaran pengeluaran kolostrumhypnobreasfeding $48,6 \%$ dan $51,4 \%$ pijat oksitosin.

\section{Hasil Bivariat}

Hubungan hypnobreasfeeding dan pijat oksitosin dengan pengeluaran kolostrum pada ibu post partum

Tabel 2.

Waktu pengeluaran kolostrum 2 jam 4 jam pada ibu Postpartum terhadap hypnobreasfeeding Di Puskesmas Kecamatan Cimanggis Tahun 2017

\begin{tabular}{lcccc}
\hline \multicolumn{1}{c}{ Variabel } & Ya & Tidak & Total & P Value \\
\hline $\begin{array}{l}\text { Waktu pengeluaran kolostrum } \\
\text { Usia Reproduksi : }\end{array}$ & & & & \\
$\begin{array}{l}\text { Reproduksi sehat } \\
\text { Resiko }\end{array}$ & $14(23.7)$ & $45(76.3)$ & $59(100)$ & 0.513 \\
$\begin{array}{l}\text { Paritas : } \\
\text { Multi }\end{array}$ & $5(33.3)$ & $10(66.7)$ & $15(100)$ & \\
& $17(35,4)$ & $31(64,6)$ & $48(100)$ & 0.020 \\
\hline
\end{tabular}




\begin{tabular}{lccc}
\hline $\begin{array}{l}\text { Primi } \\
\text { Waktu pengeluaran kolostrum }\end{array}$ & $2(7,7)$ & $24(92,3)$ & $26(100)$ \\
Usia Reproduksi : & & & \\
$\begin{array}{l}\text { Reproduksi sehat } \\
\text { Resiko }\end{array}$ & $35(59,3)$ & $24(40,7)$ & $59(100)$ \\
Paritas : & $10(66,7)$ & $5(33,3)$ & $15(100)$ \\
Multi & & & \\
Primi & $35(72,9)$ & $13(27,1)$ & $48(100)$ \\
\hline
\end{tabular}

Berdasarkan Tabel 2. Menunjukan bahwa waktu pengeluaran kolostrum 2 jam $23,7 \%$ pada usia reproduksi sehat dan $33,3 \%$ pada usia reproduksi resiko. Untuk paritas multigravida 64,6\%. Dimana variabel paritas ini berhubungan terhadap pengeluaran kolostrum 2 jam pertama dengan pvelue 2.020.
Pengaruh Hypnobreasfeeding, Pijat Oksitosin Terhadap Pengeluaran Kolostrum 2 jam nifas dan 4 jam nifas ( Umur, Paritas )

Tabel 3.

Faktor Dominan Hypnobreasfeeding Terhadap Waktu Pengeluaran Kolostrum

\begin{tabular}{llrcc}
\hline Variabel Independen & $\begin{array}{c}\mathbf{2} \text { jam } \\
(\mathbf{F})\end{array}$ & $\begin{array}{c}\mathbf{4} \text { jam } \\
(\mathbf{S i g})\end{array}$ & $\begin{array}{l}\text { ( F }) \\
(\mathbf{S i g})\end{array}$ \\
\hline Umur & .020 & .889 & .098 & .755 \\
Paritas & 2.460 & .121 & .5 .575 & .021 \\
\hline
\end{tabular}

Hasil analisi multivariat dengan dengan regresi logistik pada tabel 3. Ternyata faktor dominan yang paling berpengaruh terhadap pengeluaran kolostrum adalah paritas multi gravida yang dilakukan hypnobreasfeeding dan pijat oksitosin pada 4 jam masa nifas.

Berdasarkan hasil perhitungan maka didapatkan informasi secara objektif bahwa terdapat pengaruh langsung dan tidak langsung dari hypnobreasfeeding, pijat oksitosin, usia reproduksi dan paritas terhadap pengeluaran kolostrum pada ibu post partum yang akan diuraikan sebagai berikut.

Hasil pengujian hipotesis usia reproduksi sehat terhadap pengeluaran kolostrum 2 jam pertama post partum, menunjukan bahwa variabel usia reproduksi berpengaruh terhadap pengeluaran kolostrum 2 jam pertama post partum sebesar .447 lebih besar dari 0,05 maka artinya tidak ada pengaruh antara usia 
reproduksi sehat terhadap pengeluaran kolostrum 2 jam pertama.

Hal ini disebabkan pada 2 jam pertama post partum ibu masih belum pulih keadaan fisik, mengalami kecemasan, stres, lelah yang berlebihan setelah persalinan karena. Keadaan tersebut diatas berpengaruh terhadap mekanisme kerja hormon prolaktin yang berperan dalam memproduksi ASI atau pengeluaran kolostrum

Hasil penelitian yang dilakukan di RS Muhammaddiyah Bandung tahun 2011 perlakuan pijat oksitosin yang dilakukan pada ibu post partum berpengaruh terhadap jumlah produksi kolostrum dengan Pvalue 0,009, namun pijat oksitosin tidak berpengaruh terhadap lama waktu pengeluaran kolostrum dengan Pvalue 0,939 .

Hasil pengujian hipotesis paritas pada ibu post partum multi gravida, menunjukan bahwa variabel paritas multi gravida berpengaruh terhadap pengeluaran kolostrum pada 4 jam pertama post partum sebesar $0.04>$ dari 0,05 maka artinya tidak ada pengaruh paritas multi gravida terhadap pengeluaran kolostrum 4 jam post partum.

Berdasarkan penelitian Joeharno dan Zaenab ( 2009 ), bahwa paritas multi gravida berisiko lebih besar mengalami permasalahan kesehatan baik bagi ibu maupun bayi yang dilahirkan. Menurut Lewellyn-Jones ( 2008 ), ibu dengan paritas yang tinggi lebih mungkin menderita komplikasi pada kehamilan, persalinan maupun pada saat masa nipas atau post partumnya. Keadaan kesehatan ibu post partum yang tidak prima akan berdampak terhadap pengeluaran kolostrum maupun ASI.

Hasil penelitian Joeharno dan Zaenab tidak sesuai dengan penelitian yang kami lakukan karena penelitian yang dilakukan mempunyai perbedaan variabel, analisa data, lokasi penelitian, jumlah responden Hasil pengujian faktor dominan yang berpengaruh terhadap pengeluaran kolostrum adalah paritas multi gravida yang dilakukan hypnobreasfeeding dan pijat oksitosin pada 4 jam masa nifas. Pada 4 jam masa nifas diharapkan ibu sudah memiliki waktu yang cukup untuk istirahat. Perasaan lelah, stres, dan tidak nyaman sudah tidak dirasakan sehingga hal tersebut mendukung dilakukannya intervensi yang akan dilakukan, salah satu intervensi adalah hypnobreasfeeding atau pijat oksitosin yang mempunyai pengaruh terhadap pengeluaran kolostrum. Hasil penelitian tersebut sesuai dengan pendapat Lanny Kuswandi (2014) dalam bukunya Hypnobreasfeeding Untuk Pengeluaran Kolostrum. 


\section{SIMPULAN}

Berdasarkan hasil dan pembahasan penelitian pada bab sebelumnya dapat peneliti simpulkan tentang Pengaruh Hypnobreasfeeding, Pijat Oksitosin Terhadap Pengeluaran Kolostrum Pada Ibu Post Partum meliputi waktu pengeluaran kolostrum, reproduksi sehat, paritas sebagai berikut :

Gambaran pada ibu post partum yang mendapatkan perlakuan dengan Hypnobreasfeeding, Pijat Oksitosin berdasarkan paritas pada 2 jam pertama post partum didapatkan hasil tidak ada pengaruh antara paritas dengan pengeluaran kolostrum 2 jam pertama.

\section{DAFTAR RUJUKAN}

Departemen Kesehatan RI. 2009. Informasi Seputar Kesehatan Bayi Baru Lahir. Direktorat Bina Kesehatan Anak Jakarta.

Guyton. 2009. Buku Ajar Fisiologi Kedokteran, Edisi 11, Buku Kedokteran EGC. Jakarta.

Hanifa Wiknjosastro. 2009. Ilmu Kebidanan. Yayasan Bina Pustaka Sarwono Prawirohardjo. Jakarta.

Kuswandary, Hypnobreasfeeding. 2013 (online) www.asi.com. Diunduh pada tanggal 19 Pebruari 2016.

Perenesia. 2008. Pelatihan Konseling Menyusui. Jakarta.
Pijat Oksitosin berdasarkan usia pada 4 jam post partum didapatkan hasil tidak ada pengaruh antara usia reproduksi dengan pengeluaran kolostrum 4 jam post partum, pijat oksitosin paritas pada 4 jam post partum, didapatkan hasil ada pengaruh pada ibu post partum multi gravida terhadap pengeluaran kolostrum 4 jam post partum. Faktor dominan yang berpengaruh terhadap pengeluaran kolostrum adalah tindakan hypnobreasfeeding dan pijat oksitosin pada multi gravida yang dilakukan pada waktu 4 jam post partum

Permeneg. Pemberdayaan Perempuan dan Perlindungan Anak. RI No.3 Tahun 2010

Kriebs, Jan M. 2010 . Asuhan Kebidanan Varney, Edisi 2. Buku Kedokteran.

Kadir. 2010. Statistika, Untuk Penelitian Ilmu-Ilmu Sosial. Jakarta : Rosemanta Sampurna. p. 176.

Fimela, Lancar Menyusui dengan Hypnobreasfeeding. 2013 ( online ) www.family.fimela. Diunduh tanggal 19 Pebruari 2016.

Lanny Kuswandi. 2014. Hypnobreasfeeding dan Pijat Oksitosin. Jakarta : PT. Gramedia Pustaka Utama.

Nia Umar. 2014. Multitaskin Breasfeeding Mama. Jakarta : Pustaka Bunda, Group Puspa Swara. 